\title{
Economic losses due to the occurrence of cysticercosis in cattle from cities located in Minas Gerais, Brazil
}

\author{
Maria Teresa Nunes Pacheco Rezende ${ }^{1,2^{*}} \odot$ Raquel Satomi Komatsu ${ }^{2} \odot$ \\ Renata Barbosa Andrade ${ }^{2}$ - Serly Lourenço Borges Reis ${ }^{2}$ () Claudesina Rodrigues Leite ${ }^{2}$ \\ Stella Rabelo Rocha ${ }^{3}$ ) João Paulo Elsen Saut ${ }^{1}$ () Ednaldo Carvalho Guimarães ${ }^{1}(\mathcal{C})$
}

\author{
${ }^{1}$ Programa de Pós-graduação em Ciências Veterinárias, Universidade Federal de Uberlândia (UFU), Uberlândia, MG, Brasil. \\ ${ }^{2}$ Secretaria Municipal de Agropecuária, Abastecimento e Distritos da Prefeitura Municipal de Uberlândia, 38413-097, Uberlândia, MG, Brasil. \\ E-mail: mtprezende@yahoo.com.br. "Corresponding author. \\ ${ }^{3}$ Médica Veterinária, Monte Carmelo, MG, Brasil.
}

\begin{abstract}
Cysticercosis represents an important public health problem that can cause significant economic losses to the beef industry. The present study aimed to determine the prevalence rate of cysticercosis in cattle and estimate the economic losses to producers associated with this parasitic disease. Data were collected from the official sanitary inspection service of a slaughterhouse located in the city of Uberlândia, Minas Gerais, southeast Brazil, from 2009 to 2016. A total of 358,383 cattle from 46 cities in Minas Gerais, Brazil, were slaughtered, of which 4,243 were infected with cysticercosis (1.18\%). A total of 5,194 cysticerci were detected in these carcasses, of which 4,548 (87.56\%) were alive and $646(12.44 \%)$ were calcified. Most of the cysticerci were located in the masseter and pterygoid masticatory muscles (72.41\%). As to the classification of cysticercosis according to the degree of infection of organs and/or parts affected, mild infection was the most frequently observed (92.36\%). Rural producers had a total of R\$1,755,204.20 (US\$ 537,526.80) of economic losses due to bovine cysticercosis during the time span of eight years covered by this retrospective study. The importance of the sanitary inspection of meat in the control of this major zoonotic diseases is emphasized.
\end{abstract}

Key words: cysticercus, sanitary inspection of meat, Taenia saginata, zoonosis.

Perdas econômicas devido à ocorrência de cisticercose em bovinos procedentes de municípios localizados em Minas Gerais, Brasil

RESUMO: A cisticercose representa um importante problema de saúde pública que pode causar prejuízos econômicos impactantes para a cadeia da carne bovina. Objetivou-se com este estudo determinar a frequência da ocorrência de cisticercose em bovinos e as perdas econômicas aos produtores. Foram coletados dados do serviço de inspeção sanitária oficial de um abatedouro frigorífico de Uberlândia, Estado de Minas Gerais, Brasil, no periodo de 2009 a 2016. Foram abatidos 358.383 bovinos, provenientes de 46 municipios de Minas Gerais, sendo que destes, 4.243 estavam infectados com cisticercose (1,18\%). Foram detectados um total de 5.194 cisticercos, sendo 4.548 $(87,56 \%)$ vivos e $646(12,44 \%)$ calcificados. A maioria dos cisticercos estava localizada nos músculos mastigatórios masseteres e pterigóides $(72,41 \%)$. Quanto à classificação da cisticercose, de acordo com o grau de infecção dos órgãos elou partes, a infecção discreta foi a que mais ocorreu $(92,36 \%)$. Verificou-se que os produtores rurais tiveram um total de R\$1.755.204,20 (US\$537.526,80) de perdas econômicas durante o periodo analisado de oito anos devido à ocorrência de cisticercose no rebanho bovino. Destacou-se a importância da inspeção sanitária de carnes, no controle desta importante zoonose.

Palavras-chave: cisticercose, inspeção sanitária de carne, Taenia saginata, zoonose.

\section{INTRODUCTION}

Cysticercosis is the most frequently diagnosed zoonotic disease in post mortem examinations of cattle in slaughterhouses in Brazil, and represents an important socioeconomic and public health issue (SANTOS and MOREIRA, 2010). According to SOUZA et al. (2007), losses due to bovine cysticercosis can cause direct economic losses of R\$ 24.5 million/year to the country.
The teniasis-cysticercosis complex in cattle occurs in two distinct forms: teniasis which is characterized by human infection with the adult form of Taenia saginata, and cysticercosis which is caused by the larval stage of this tapeworm that occur in various bovine organs and tissues. Humans become infected by consuming raw or undercooked beef containing viable cysticerci (CARVALHO et al., 2006).

As for the risk factors for infection with bovine cysticercosis, the following aspects should 
be highlighted in the disease epidemiology: supply of contaminated feed roughage to cattle, use of agricultural land for leisure or tourism, flooding of pastures, socio-economic conditions of the population, free access to surface water bodies (rivers, lakes and canals), as well as proximity to an effluent or waste water source (MAGALHÃES et al., 2017; DUARTE et al., 2016). According to MARSHALL et al. (2016), cattle from farms located near a potential permanent source of human fecal contamination and that use manure from animals other than cattle have a higher risk of developing cysticercosis. MAIA et al. (2017) reported high seroprevalence of bovine cysticercosis in the state of Paraíba and identified as risk factors the purchase of animals and flooded pastures and ROSSI et al. (2015) indicated as risk factors access of cattle to sources of uncontrolled water, as well as sports fishing activities near the farms.

Despite the low sensitivity of the postmortem examination, especially in mild infections (MINOZZO et al., 2004), MAGALHÃES et al. (2017) emphasized the importance of hygienicsanitary and technological inspection in obtaining bovine meat. Consumption of raw meat that does not undergo rigorous inspection is considered the main risk factor for the occurrence and maintenance of the of teniasis-cysticercosis complex in cattle.

Cysticercosis remains endemic in Brazil. This important disease is responsible for major economic losses to the beef industry. Therefore, interventions are necessary to keep Brazilian beef competitive on the international food market and to improve food security for the population (ROSSI et al., 2017).

The present study was carried out with the objective of assessing the prevalence of cysticercosis in cattle from cities located in the of Minas Gerais, southeast Brazil, that were sent to a slaughterhouse under official sanitary inspection at the city of Uberlândia, Minas Gerais, Brazil, as well as to estimate economic losses to producers associated with this parasitic disease.

\section{MATERIALS AND METHODS}

In this retrospective survey, we used data from the files of the Municipal Inspection Service - SIM which is linked to the Brazilian System of Inspection of Products of Animal Origin - SISBI/ POA, which is related to the slaughter of cattle. We collected archived data from a slaughterhouse located in the municipality of Uberlândia, Minas Gerais, in the Southeastern region of the country, from January 2009 to December 2016.
Data on cattle that were slaughtered during this 8-yeartime span were analyzed, totaling 358,383 animals, including males and females, with ages ranging between 18 to 60 months, from 46 municipalities in the State of Minas Gerais, southeast Brazil, including: Abadia dos Dourados, Água Comprida, Araguari, Araporã, Araxá, Buritizeiro, Campina Verde, Canápolis, Capinópolis, Carmo do Paranaíba, Centralina, Comendador Gomes, Conceição das Alagoas, Coromandel, Douradoquara, Estrela do Sul, Frutal, Gurinhatã, Grupiara, Ibiá, Indianópolis, Iraí de Minas, Itapagipe, Ituiutaba, João Pinheiro, Monte Alegre de Minas, Monte Carmelo, Nova Ponte, Paracatu, Patos de Minas, Patrocínio, Pedrinópolis, Perdizes, Pirapora, Prata, Presidente Olegário, Romaria, Sacramento, Santa Juliana, Santa Vitória, Tupaciguara, Uberaba, Uberlândia, Varjão de Minas, Vazante, and Veríssimo. Cattle identification and traceability was performed based on the Animal Transit Guidelines - GTAs. This system was used to verify the origin of the bovine herd and identify areas with an increased risk for the occurrence of cysticercosis.

Hygienic-sanitary and technological processing of cattle slaughter was carried out as recommended by the following Standards: Meat Inspection - Standardization of Cattle Slaughter Techniques, Facilities, and Equipment of the Brazilian Ministry of Agriculture, Livestock and Supply (BRASIL, 1971) and Regulation of Industrial and Sanitary Inspection of Animal Products - RIISPOA (BRASIL, 2017). For the evaluation and diagnosis of cysticercosis during the post mortem inspection at the slaughterhouse/ meat inspection plant, inspection agents from the Municipal Inspection Service - SIM working in slaughter inspection performed palpation and visual examination of the heads, víscera and carcasses of the animals as well as incisions of lymph nodes, masseter muscles, pterygoid muscles, tongue, heart, muscular portion and pillars of the diaphragm, esophagus, and muscles from the front quarter and hindquarter of the carcasses. The carcasses and organs affected by cysticercosis in the inspection lines were retained and diverted to the Department of Final Inspection - DIF for careful examination, classification, judgment, and destination of the meat by the supervising veterinarian/ meat inspector from SIM.

Cystic lesions with a translucent or slightly opaque wall, containing clear fluid and a small, round structure inside i.e. the scolex, were considered as living cysticerci. Lesions were interpreted as calcified cysticerci when presented with a fibrous capsule adhered to the surrounding tissue containing a whitish to yellowish material, with a caseous and/or calcareous appearance. As to the degree of infection, cysticercosis was classified as severe when at least eight viable or calcified cysts were found distributed 
in the carcass as follows: two or more cysts simultaneously located in at least two selected sites simultaneously located in at least two selected sites of the carcass examined at the slaughter inspection (masticatory muscles, tongue, heart, diaphragm and its pillars, esophagus, and liver), totaling at least four cysts; and four or more cysts located in the forequarter (neck, chest, and palate muscles) or in the rear quarter (thigh, rump, and loin) muscles.

Infection was classified as moderate when more than one viable or calcified cyst and less than that determined for severe infection were reported at the sites of the carcass selected for examination in the slaughter inspection. Infection was classified as mild when only a single viable or calcified cyst was reported at the sites of the carcass selected for examination in the slaughter inspection.

The carcasses and organs in which severe infection was observed were condemned. Discarded specimens were sent to the unit of processing of inedible products. Those classified as having moderate infection had the affected parts removed and condemned and were then destined to conditional use by the use of heat, cooking at a temperature of $76.6^{\circ} \mathrm{C}$ for at least 30 minutes, or heat melting at a minimum temperature of $12^{\circ} \mathrm{C}$. Carcasses and organs in which the infection was classified as mild, the affected sites removed and condemnation and were then subjected to conditional cold treatment at a temperature no higher than $-10^{\circ} \mathrm{C}$ for at least 10 days. An economic analysis of the losses of farmers related to bovine cysticercosis was made regarding the $25 \%$ discount applied for carcasses with mild cysticercosis which were destined to cold thermal treatment, $50 \%$ for carcasses with moderate cysticercosis that were destined to heat treatment, and $100 \%$ for carcasses with severe cysticercosis which were condemned and destined to the processing unit of inedible products. Arroba values were based on data provided by the Center for Advanced Studies in Applied Economics - CEPEA of ESALQ/USP, Brazil, for the month of December of each corresponding year.

Data on cysticercosis were recorded in specific forms and tabulated in annualized spreadsheets. To estimate the population prevalence, the $95 \%$ confidence interval for the proportion (95\% CI) was used. Organs and carcasses destined to conditional treatment or condemnation were quantified, and the economic loss of the producers associated with cysticercosis analyzed. The chisquare test of independence was used to assess the relationship between the morphological condition and the anatomical sites affected by Cysticercus infection. The binomial test for two proportions was used to compare the amount of live and calcified cysticerci and to analyze the distribution of the cases by anatomical sites. In order to indicate if the prevalence differences were real and not by chance, the chi-square test of adherence was used. All analyses were carried out considering a significance of 5\% (AYRES et al., 2005).

\section{RESULTS AND DISCUSSION}

The prevalence of bovine cysticercosis was $1.18 \%(4,243 / 358,383)$, with a decrease in these values during the eight years covered by this survey (Table 1). The municipalities with the highest

Table 1 - Prevalence of cysticercosis and the different degrees of infection in cattle from 46 municipalities in the state of Minas Gerais, southeast Brazil, slaughtered under official sanitary inspection between 2009 and 2016.

\begin{tabular}{|c|c|c|c|c|c|c|}
\hline \multirow[t]{2}{*}{ Year } & \multirow[t]{2}{*}{ Number of Slaughtered } & \multicolumn{5}{|c|}{---"--"-} \\
\hline & & Number of Cases & Prevalence $\%(\text { IC } 95 \%)^{*} \%$ & Mild & Moderate & Severe \\
\hline 2009 & 38,398 & 820 & $2.10(1.90-2.30)$ & 776 & 32 & 12 \\
\hline 2010 & 43,670 & 738 & $1.69(1.57-1.81)$ & 713 & 22 & 3 \\
\hline 2011 & 35,805 & 552 & $1.54(1.42-1.67)$ & 535 & 11 & 6 \\
\hline 2012 & 35,888 & 417 & $1.16(1.06-1.28)$ & 375 & 35 & 7 \\
\hline 2013 & 49,138 & 395 & $0.80(0.70-0.90)$ & 372 & 18 & 5 \\
\hline 2014 & 54,493 & 372 & $0.68(0.62-0.76)$ & 337 & 26 & 9 \\
\hline 2015 & 48,959 & 516 & $1.05(0.97-1.15)$ & 448 & 46 & 22 \\
\hline 2016 & 52,032 & 433 & $0.83(0.75-0.91)$ & 363 & 53 & 17 \\
\hline TOTAL & 358,383 & 4,243 & $1.18(1.15-1.22)$ & 3,919 & 243 & 81 \\
\hline
\end{tabular}

${ }^{*} 95 \%$ CI: Confidence interval at $95 \%$ level. 
prevalence of bovine cysticercosis in Minas Gerais, southeast Brazil, were Monte Alegre de Minas (4.1\%), Tupaciguara (3.8\%), and Santa Juliana (2.7\%).

ROSSI et al. (2017) carried out a study in 19 Brazilian states between years of 2010 and 2015, and showed a prevalence of $0.62 \%$ of bovine cysticercosis. In their study, Paraná $(2.01 \%)$, Santa Catarina (1.96\%), São Paulo (1.77\%), Rio Grande do Sul (1.63\%) and Mato Grosso do Sul (0.80\%) had the highest prevalences of cysticercosis in cattle. PEREIRA et al. (2006) reported a prevalence rate of $1.95 \%$ in the State of Rio Janeiro. According to LARANJO-GONZÁLEZ et al. (2016), the prevalence of bovine cysticercosis in most countries in Europe is below 1\%. The prevalence of this disease in Belgium based on data published by the official sanitary inspection of that country is estimated at $0.22 \%$ (JANSEN et al., 2017). In a study conducted in France by DUPUY et al. (2014), the authors reported a prevalence of bovine cysticercosis of $0.142 \%$. These researchers emphasized the importance of the efficacy in the detection of cysticerci, and suggested the implementation of riskbased inspection procedures in order to improve the prevention of human infection considering the fact that a carcass may infect an average of eight to 20 individuals. Eating habits in France should also be considered. French people usually eat undercooked meat. Consumption of undercooked meat greatly increases the risk of humans becoming infected by viable cysticercus which may go unnoticed during the routine postmortem examination of cattle slaughter inspection.

Masseter and pterygoid muscles were the anatomic sites most affected in the carcasses examined with a prevalence of $72.41 \%(3,761 / 5,194)$, followed by the heart, $19.97 \%(1,037 / 5,194)$, diaphragm, $2.12 \%(110 / 5,194)$,tongue, $1.79 \%(93 / 5,194)$, muscles of the forequarters, $1.47 \%(76 / 5,194)$, esophagus, $1.13 \%(59 / 5,194)$, muscles of the hindquarters, $0.86 \%(45 / 5,194)$, and the liver, $0.25 \%(13 / 5,194)$. In a study conducted by FRUET et al. (2013) in Santa Maria, State of Rio Grande do Sul, south Brazil, the heart was the organ most affected by cysticercosis. In contrast, SOUZA et al. (2007) reported a higher prevalence of the parasite in the muscles of the head $(57.77 \%)$ followed by the heart $(39.65 \%)$. Our findings are in agreement with the ones previously published by these authors.

Knowledge on the most frequent sites in which cysticerci occur in bovine carcasses and organs is important in order to improve the efficiency of meat inspection in slaughterhouses. However there remains controversy among authors about the site where this parasite preferentially occurs in cattle (SOUZA et al., 2007). According to COSTA et al. (2012), cysticerci occurs mainly in the muscles that are better irrigated. In the present study, the number of live cysticerci that were reported in the carcasses and organs of cattle during postmortem examination, 87.56\% $(4,548 / 5,194)$, was higher than that of calcified cysticerci, $12.44 \%$ $(646 / 5,194)$, with $p<0.0001$. The chi-square test showed an association between the presence of cysticerci live or calcified and predilection sites in the carcass considered in the diagnosis of this disease during slaughter inspection. There was a significant difference $(\mathrm{p}<0.0001)$ between frequencies according to the morphological condition and anatomical site (Table 2). In a

Table 2 - Site and morphological condition of cases of cysticercosis detected in cattle slaughtered and inspected in Minas Gerais, Brazil, between 2009 and 2016 .

\begin{tabular}{|c|c|c|c|c|}
\hline \multirow[t]{2}{*}{ Site/Morphology } & \multicolumn{2}{|c|}{--------Live cysticercus------- } & \multicolumn{2}{|c|}{-------Calcified cysticercus------ } \\
\hline & $\mathrm{N}$ & $\%$ & $\mathrm{~N}$ & $\%$ \\
\hline Masseters and Pterygoids & 3,397 & 74.70 & 364 & 56.35 \\
\hline Heart & 835 & 18.36 & 202 & 31.28 \\
\hline Diaphragm & 94 & 2.06 & 16 & 2.47 \\
\hline Tongue & 72 & 1.58 & 21 & 3.25 \\
\hline Foreleg (forelimb, anterior, front quarter, forequarter) muscles & 58 & 1.27 & 18 & 2.78 \\
\hline Esophagus & 47 & 1.04 & 12 & 1.86 \\
\hline Hind leg (hindlimb, posterior, rear quarter, hindquarter) muscles & 34 & 0.75 & 11 & 1.70 \\
\hline Liver & 11 & 0.24 & 2 & 0.31 \\
\hline Total & 4,548 & 100 & 646 & 100 \\
\hline
\end{tabular}

$\mathrm{X}^{2}$ for independence $=92.25(\mathrm{p}<0.00001)$. 
survey carried out in the state of Mato Grosso, Central West Brazil, ROSSI et al. (2016) detected a higher frequency of calcified cysticerci (74.43\%). These authors highlighted the need to develop a study model based on risk analysis as to the origin of the animals in order to improve the detection of cysticerci in endemic areas.

GARRO et al. (2015) reported a seroprevalence of $4.10 \%$ for bovine cysticercosis and a frequency of $2.94 \%$ for human teniasis in the municipality of São João Evangelista, Minas Gerais, southeast Brazil. In their study, consumption of rare beef was the main risk factor for the maintenance of the teniasis-cysticercosis complex. These results are in agreement to those reported by MAGALHÃES et al. (2017) in the municipality of Salinas, Minas Gerais, Brazil.

As to the different degrees of cysticercosis infection, mild infection, $92.36 \%(3,919 / 4,243)$, was the most frequently observed in our study (Table 1). The average weight of the carcasses was 14 arrobas $(210 \mathrm{~kg})$. We noted that rural producers had a total economic loss of R $\$ 1,755,204.20$ (US\$ $537,526.80$ ) due cysticercosis in the bovine herds during the eight years period covered by this survey (Table 3). ROSSI et al. (2015) detected cysticercosis in $58.45 \%$ of cattle farms that supplied an export slaughterhouse in the São Paulo, southeast Brazil, in 2012. Estimates of economic losses were US \$ 312,194.52.

Post mortem inspection is an important and specific method to identify cysticercosis in cattle during slaughter. This technique, based on the macroscopic Gross detection of live or calcified cysticerci in carcasses and viscera with mild, moderate and severe infections serves as an early warning of the degree of infection in a property or community. It reinforces the importance of sanitary and technological inspection for the control of the teniasis-cysticercosis complex (MINOZZO et al., 2004; PEREIRA et al., 2006).

\section{CONCLUSION}

Our findings showed that bovine cysticercosis occur in 46 municipalities of Minas Gerais, southeast Brazil, and demonstrate a prevalence rate of $1.18 \%$ of this parasitic disease. Bovine cysticercosis has a direct economic impact on producers who; therefore, can subsidize control measures against this zoonotic disease of major importance in terms of public health.

Table 3 - Simulation of losses (discounts of $25 \%, 50 \%$, and $100 \%$ ) generated to rural producers in Brazil due to the occurrence of cysticercosis in bovine herds from 2009 to 2016.

\begin{tabular}{|c|c|c|c|c|c|c|c|c|c|c|c|}
\hline Year & $\begin{array}{c}\text { Total } \\
\text { weight }^{1} \\
\text { Mild }\end{array}$ & $\begin{array}{c}\text { Total } \\
\text { weight }^{1} \\
\text { Modera } \\
\text { te }\end{array}$ & $\begin{array}{c}\text { Total } \\
\text { weight }^{1} \\
\text { Severe }\end{array}$ & $\begin{array}{c}\text { value } \\
\mathrm{R} \$^{2}\end{array}$ & $\begin{array}{l}\text { Value } \\
\text { US\$ }^{2}\end{array}$ & $\begin{array}{c}25 \% \\
\text { discount } \\
\mathrm{R} \$\end{array}$ & $\begin{array}{c}25 \% \\
\text { discount } \\
\text { US\$ }\end{array}$ & $\begin{array}{c}50 \% \\
\text { Discoun } \\
\text { t R\$ }\end{array}$ & $\begin{array}{c}50 \% \\
\text { Discoun } \\
\text { t US\$ }\end{array}$ & $\begin{array}{c}100 \% \\
\text { Discoun } \\
\text { t R\$ }\end{array}$ & $\begin{array}{c}100 \% \\
\text { Discoun } \\
\text { t US\$ }\end{array}$ \\
\hline 2009 & 10,864 & 448 & 168 & 71 & 23 & 192,836 & 61,219 & 15,904 & 5,049 & 11,928 & 3,787 \\
\hline 2010 & 9,982 & 308 & 42 & 92 & 29 & 229,586 & 72,894 & 14,168 & 4,498 & 3,864 & 1,227 \\
\hline 2011 & 7,490 & 154 & 84 & 92 & 29 & 172,270 & 54,696 & 7,084 & 2,249 & 7,728 & 2,454 \\
\hline 2012 & 5,250 & 490 & 98 & 88 & 28 & 115,500 & 36,671 & 21,560 & 6,845 & 8,624 & 2,738 \\
\hline 2013 & 5,208 & 252 & 70 & 106 & 34 & 138,012 & 43,812 & 13,356 & 4,240 & 7,420 & 2,356 \\
\hline 2014 & 4,718 & 364 & 126 & 137 & 44 & 161,592 & 51,296 & 24,934 & 7,915 & 17,262 & 5,48080 \\
\hline 2015 & 6,272 & 644 & 308 & 145 & 38 & 227,360 & 59,584 & 46,690 & 12,236 & 44,660 & 11,704 \\
\hline 2016 & 5,082 & 742 & 238 & 148 & 45 & 188,034 & 57,173 & 54,908 & 16,695 & 35,224 & 10,710 \\
\hline Total & 54,866 & 3,402 & 1,134 & - & - & $1,419,890$ & 437,344 & 198,604 & 59,728 & 136,710 & 40,455 \\
\hline
\end{tabular}

1 - Estimated average weight in 14 arrobas $(210 \mathrm{Kg})$.

2 - Market value referring to the month of December of the corresponding year according to CEPEA - Center for Advanced Studies in Applied Economics - ESALQ/USP (Brazil). 


\section{DECLARATION OF CONFLICTING INTERESTS}

The authors declare no conflict of interest. The founding sponsors had no role in the design of the study; in the collection, analyses, or interpretation of data; in the writing of the manuscript, and in the decision to publish the results.

\section{AUTHOR' CONTRIBUITIONS}

The authors contributed equally to the manuscript.

\section{REFERENCES}

AYRES, M. et al. BioEstat 4.0: Aplicações estatísticas nas áreas das ciências biológicas e médicas. Belém: Sociedade Civil Mamirauá, Brasília: CNPq, 2005, 324p. Available from: <https:// www.mamiraua.org.br/pt-br/publicacoes/publicacoes/2005/ livros/bioestat-40-aplicacoes-estatisticas-nas-areas-das-cienciasbiologicas-e-medicas/>. Accessed: May 22, 2018.

BRASIL. Ministério da Agricultura, Pecuária e Abastecimento - MAPA. Regulamento de Inspeção Industrial e Sanitária de Produtos de Origem Animal (RIISPOA). (Aprovado pelo Decreto ${ }^{\circ}$ 9.013, de 29 de março de 2017). Diário Oficial de União, Seção 1 - 30/03/2017, p. 3. Brasília, 2017, 105p. Available from: $<$ http://www.planalto.gov.br/ccivil_03/_ato2015-2018/2017/ decreto/d9013.htm>. Accessed: May 22, 2018.

BRASIL. Inspeção de Carnes Bovina - Padronização de Técnicas, Instalações e Equipamentos do Abate de Bovinos. Brasília: Ministério da Agricultura, Pecuária e Abastecimento, 1971. Available from: <http://www.agricultura. gov.br/assuntos/inspecao/produtosanimal/empresario/copy_of TOMODEBOVINO.pdf>. Accessed: May 22, 2018.

CARVALHO, L. T. et al. Prevalence of cysticercosis in cattle slaughtered in a slaughterhouse under federal inspection in Minas Gerais. Revista Brasileira de Ciência Veterinária, Niterói, v. 13, n. 2, p. 109-112, 2006. Available from: <http://periodicos. uff.br/rbcv/article/view/7146/5428>. Accessed: May 22, 2018. doi:10.4322/rbcv.2014.280.

CEPEA - Centro de Estudos Avançados em Economia Aplicada - ESALQ/USP. Available from: < http://www.cepea.esalq.usp.br>. Accessed: Oct. 04, 2016.

COSTA, R.F.R. et al. Characterization of lesions by Cysticercus bovis, in the post-mortem inspection of cattle, by macroscopic, histopathological and polymerase chain reaction (PCR). Pesquisa Veterinária Brasileira, v.32, n.6, p.477-484, Jun. 2012. Available from: <http://dx.doi.org/10.1590/S0100736X2012000600002>. Accessed: May 22, 2018. doi: 10.1590/ S0100-736X2012000600002.

DUARTE, C.T.D. et al. Profile of transmission and prevalence of bovine cysticercosis in rural properties of Triângulo Mineiro. Pesquisa Veterinária Brasileira, v.36, n.9, p.793-797, set. 2016. Available from: $<$ http://dx.doi.org/10.1590/s0100-736x2016000900001>. Accessed: May 22, 2018. doi: 10.1590/s0100-736x2016000900001.

DUPUY, C. et al. Prevalence of Taenia saginata cysticercosis in French cattle in 2010. Veterinary Parasitology, v.203, n.1-2, p.65-72, Jun. 2014. Available from: <http://doi.org/10.1016/j. vetpar.2014.02.054>. Accessed: May 31, 2018. doi: 10.1016/j. vetpar.2014.02.054.

FRUET, A.P.B. et al. Economic losses resulting from convictions of bovine offal in slaughterhouses of Santa Maria, Rio Grande do Sul. Revista Brasileira de Ciência Veterinária, v.20, n.2, p.99103, abr./jun. 2013. Available from: <http://dx.doi.org/10.4322/ rbcv.2014.053> Accessed: May 22, 2018. doi: 10.4322/ rbcv.2014.053.

GARRO, F.L. et al. Diagnosis of the teniase-bovine cysticercosis complex in São João Evangelista, Minas Gerais, Brazil. Arquivo Brasileiro de Medicina Veterinária e Zootecnia, v.67, n.4, p.1063-1069, 2015. Available from: <http://dx.doi. org/10.1590/1678-4162-8196>. Accessed: May 22, 2018. doi: $10.1590 / 1678-4162-8196$

LARANJO-GONZÁLEZ, M. et al. Epidemiology, impact and control of bovine cysticercosis in Europe: a systematic review. Parasites \& Vectors, v. 9, p. 1-12. 2016. Available from: <http:// doi.org/10.1186/s13071-016-1362-3>. Accessed: May 31, 2018. doi: 10.1186/s13071-016-1362-3.

MAGALHÃES, F.C. et al. Diagnosis and risk factors of the teniase-bovine cysticercosis complex in the city of Salinas, Minas Gerais. Pesquisa Veterinária Brasileira, v.37, n.3, p.205-209, mar. 2017. Available from: <http://dx.doi.org/10.1590/s0100736x2017000300001>. Accessed: May 22, 2018. doi: 10.1590/ S0100-736X2017000300001.

MAIA, A.R.A et al. Herd-level seroprevalence and associated risk factors for bovine cysticercosis in the State of Paraíba, Northeastern Brazil. Preventive Veterinary Medicine, v.142, p.51-57, jul. 2017. Available from: <https://doi.org/10.1016/j. prevetmed.2017.05.008>. Accessed: May 09, 2018. doi: 10.1016/j. prevetmed.2017.05.008.

MARSHALL, L.R. et al. Risk factors for Taenia saginata cysticercus infection in cattle in the United Kingdom: A farm-level case-control study and assessment of the role of movement history, age and sex. Preventive Veterinary Medicine, v.135, p.1-8, dez. 2016. Available from: <https://doi.org/10.1016/j.prevetmed.2016.10.015>. Accessed: May 09, 2018. doi: 10.1016/j.prevetmed.2016.10.015

MINOZZO, J.C et al. Enzyme-linked immunosorbent assay for the diagnosis of bovine cysticercosis and study of the kinetics of antiCysticercus bovis antibody production. Ciência Rural, v.34, n.3, p.857-864, mai-jun. 2004. Available from: <http://www.scielo.br/ pdf/\%0D/cr/v34n3/a31v34n3.pdf>. Accessed: May 22, 2018.

PEREIRA, M.A.V.C et al. Prevalence of cysticercosis in bovine carcasses slaughtered in slaughterhouses in the State of Rio de Janeiro, submitted to SIF control, from 1997 to 2003. Arquivos do Instituto Biológico, v.73, n.1, p.83-87, jan.-mar. 2006. Available from: <http://www.biologico.sp.gov.br/uploads/docs/arq/V73_1/ pereira.PDF>. Accessed: May 24, 2018.

ROSSI, G.A.M et al. Spatial distribution of bovine cysticercosis - A retrospective study in Brazil from 2010 through 2015. Preventive Veterinary Medicine, v.145, p.145-149, set. 2017. Available from: $<$ https://doi.org/10.1016/j.prevetmed.2017.06.013>. Accessed: May 09, 2018. doi: 10.1016/j.prevetmed.2017.06.013.

ROSSI, G.A.M et al. Prevalence and geospatial distribution of bovine cysticercosis in the state of Mato Grosso, Brazil. Preventive Veterinary Medicine, v.130, p.94-98, ago. 2016. Available from: 
$<$ https://doi.org/10.1016/j.prevetmed.2016.06.008>. Accessed: May 09, 2018. doi:10.1016/j.prevetmed.2016.06.008.

ROSSI, G.A.M. et al. Bovine cysticercosis in slaughtered cattle as an indicator of Good Agricultural Practices (GAP) and epidemiological risk factors. Preventive Veterinary Medicine, v. 4, p. 504-508. Mar. 2015. Available from: <https://doi.org/10.1016/j.prevetmed.2015.01.004>. Accessed: May 31, 2018. doi: 10.1016/j.prevetmed.2015.01.004.

SANTOS, C.C.G.; MOREIRA, M.D. Occurrence of bovine cysticercosis in a slaughterhouse exporting from Ituiutaba/MG.
Cadernos de Pós-Graduação da FAZU, Uberaba, v. 1, 2010. Available from: <http://www.fazu.br/ojs/index.php/posfazu/article/ viewFile/325/231>. Accessed: Oct. 04, 2016.

SOUZA, V.K. de. et al. Anatomic regions of higher occurrence of Cysticercus bovis in cattle submitted to federal inspection in slaughterhouse-slaughterhouse in the municipality of São José dos Pinhais, Paraná, from July to December 2000. Revista Brasileira de Parasitologia Veterinária, v. 16, n. 2, p. 92-96, 2007. Available from: $<$ http://www.redalyc.org/pdf/3978/397841462007.pdf>. Accessed: May 22, 2018 